\title{
PEMIKIRAN THOMAS S. KUHN TEORI REVOLUSI PARADIGMA
}

\author{
Ulfa Kesuma $^{1}$, Ahmad Wahyu Hidayat ${ }^{2}$ \\ ${ }^{1}$ Magister Pendidikan Islam UIN Sunan Kalijaga Yogyakarta, Email: kesumaulfa@gmail.com \\ ${ }^{2}$ Kandidat Doktor UIN Sunan Kalijaga Yogyakarta, Email: ahmadwahyuhidayat95@gmail.com
}

\begin{abstract}
ABSTRAK
Tulisan ini menguraikan tentang sketsa biografi dan pemikiran Thomas Khun yang dikenal dengan jargon "revolusi ilmiah". Menurut Khun revolusi ilmiah adalah suatu teori tentang sains yang ditemukan pada satu objek dan akan terus-menerus berubah dan berkembang. Penulis menggunakan metode kepustakaan "Library Research" dan studi analisis, studi analitis yang digunakan adalah analitis historis dan analitis dokumen tentang pemikiran Thomas S Khun. Kesimpulannya bahwa Thomas Samuel Khun yang sering dipangil akrab dengan Khun memiliki banyak karya salah satunya adalah The Structure of Scientific Revolution yang di dalamnya terdapat tentang sejarah dan filsafat ilmu pengetahuan. Khun juga mengkritik teori Positifisme Auguste Comte dan Falsifikasi Karl Popper. Menurutnya, baik Auguste Comte dan Popper terlalu sibuk dengan penyelesaian teka-teki saja dan melupakan aspek penting dalam ilmu pengetahuan, yaitu paradigma. Pendapat Khun tentang paradigma yaitu suatu pendekatan investigasi suatu objek atau titik awal mengungkapkan point of view, formulasi suatu teori, mendesign pertanyaan atau refleksi yang sederhana. Akhirnya paradigma dapat di formulasikan sebagai keseluruhan sistem kepercayaan, nilai dan teknik yang digunakan bersama oleh kelompok komunitas ilmiah. Istilah "paradigma" menjadi titik tekan dalam epistimologi Thomas Khun ialah pada perkembangan ilmu secara revolusioner, dalam artian bahwa paradigma yang lama akan berkembang dengan paradigma yang baru agar mencapai suatu kebenaran yang ilmiah.
\end{abstract}

Kata Kunci : Thomas S Khun; Paradigma; Revolusioner

\begin{abstract}
This article outlines the biographical sketches and thoughts of Thomas Khun known as the "scientific revolution" jargon. According to Khun Scientific Revolution is a theory of science found on one object and will constantly change and evolve. The authors use the "Library Research" literature Method and analysis studies, the analytical studies used are historical analytical and analytical documents about Thomas S Khun's thoughts. In conclusion, Thomas Samuel Khun is often familiar with Khun has many works, one of which is The Structure of Scientific Revolution which is found in the history and philosophy of science. Khun also criticised the positive theories of Auguste Comte and falsification of Karl Popper. According to him, both Auguste Comte and Popper are too busy with the completion of the puzzle only and forget the important aspects in science, the paradigm. Khun's opinion of the paradigm is an investigative approach to an object or starting point revealing the point of view, formulation of a theory, design a simple question or reflection. Eventually the paradigm can be formulated as a whole belief system, values and techniques shared by the scientific community group. The term "paradigm" being the point of push in Thomas Khun's epistimology is on the revolutionary development of science, in the sense that the old paradigm will evolve with a new paradigm to achieve a scientific truth.
\end{abstract}

Keywords: Thomas S Khun; Paradigm; revolutionary 


\section{PENDAHULUAN}

Para ilmuwan cenderung dibentuk bukan oleh para ilmuwan itu sendiri tetapi oleh para sejarawan dan filsuf ilmu. Merekalah yang menggambarkan apa metode ilmiah itu, dan proses di mana teori-teori lama memberi jalan kepada yang baru. Apa yang mungkin masih merupakan pandangan sains yang paling umum dipegang, di antara ilmuwan dan masyarakat, adalah pandangan yang dibentuk pada 1930-an dan 1940-an oleh aliran filsuf positivis yang dikenal sebagai Lingkaran Wina. Menurut pandangan ini, sains adalah proses yang sepenuhnya logis. Ilmuwan mengajukan teori berdasarkan logika induktif, dan mengkonfirmasi atau membantahnya dengan uji eksperimental prediksi yang deduktif berasal dari teori. Ketika teori-teori lama gagal, teori-teori baru diusulkan dan diadopsi karena kekuatan penafsirannya yang lebih besar, dan dengan demikian ilmu pengetahuan semakin dekat dengan kebenaran.

Ilmu pengetahuan dan teknologi adalah dua hal yang memiliki perkembangan sangat pesat yang dibuktikan dengan banyaknya bermunculan teori-teori baru tentang ilmu pengetahuan. Hal ini menggugah Thomas Kuhn mengembangkan pikirannya yang terdapat dalam karyanya berjudul "The Structure of Scientific Revolutions" yang mengkritisi kebenaran implisit dan eksplisit didalam sains itu sendiri. Thomas. Belakangan ini sains selalu terjadi improvisasi berupa evolusi dari teori sederhana menuju teori yang lebih sempurna. Namun Kuhn menolak secara keras konsep demikian, baginya kebenaran sains tumbuh menurut revolusi ilmiah dan alamiah yakni suatu teori tentang sains ditemukan pada satu objek dan akan terus-menerus berubah walaupun kesan yang muncul lebih identik sebagai improvisasi.

Produk ilmu pengetahuan yang seharusnya mampu memberikan manfaat bagi manusia, ternyata di sisi yang lain juga merugikan manusia. Idealnya manusia bisa menguasai ilmu pengetahuan beserta produk dan metodenya. Namun tidak seperti itu kejadianya bahwa kehidupan manusia selalu terpengaruh serta merespon hasil perkembangan ilmu pengetahuan, bisa berupa positif ataupun negatif, serta ada yang mendukung atau menolak. Adanya respon ini maka perkembangan ilmu pengetahuan senantiasa terus dilakukan pengembangan sampai berada pada titik jenuh. Berikutnya adanya titik jenuh tersebut akan direspon oleh ilmuwan lain dengan melakukan pengembangan ilmu pengetahuan untuk menjawabnya.

Adopsi yang luas dari retorika sains normal, sains revolusioner, paradigma, dan contoh oleh sosiolog dari sains dan sosiolog secara umum menunjukkan pengaruh kuat itu Thomas S. Kuhn Struktur Revolusi Ilmiah $(1962,1970)$ telah memiliki penyelidikan sosiologis. Tetapi mengklaim bahwa pekerjaan Kuhn adalah anti-Mertonian, nonnormatif, relativistik, alternatif untuk positivisme dan empirisme logis, dan bahkan kompatibel dengan Marxisme adalah bagian dari semuanya mitos revolusi Kuhn dalam sosiologi sains. The dogma sentral dalam 
mitologi Kuhn adalah bahwa paradigma Kuhn adalah a signifikan, memang radikal, alternatif untuk Merton. Beberapa orang Merton telah lebih perseptif tentang Mitologi Kuhn daripada memiliki kritik sosiologi Mertonian ilmu. Gaston menyarankan (menurut saya benar) bahwa penerimaan Kuhn diperhitungkan oleh kesederhanaan dan kejelasan diskusi tentang ilmu. Namun komentar Gaston bahwa ada konsensus tentang pentingnya karya Kuhn mengabaikan perlawanan para sejarawan sains terhadap pandangan kuhn tentang sains dan perubahan ilmiah. Poin penting adalah bahwa Gaston mengenali kompatibilitas Merton dan Kuhn mencatat bahwa Kuhn dan Merton adalah tidak menentang setidaknya satu dekade setelah penerbitan Kuhn bekerja pada revolusi ilmiah. Sosiolog sains Inggris adalah pencipta utama penilaian anti-Mertonian Kuhn. Ben-David tentang reaksi Inggris dan Amerika sebagai konsekuensi yang berbeda (bukan ke menyebutkan persaingan) tradisi intelektual mungkin akurat. Tetapi bahkan Inggris cenderung mengadopsi Kuhn sebagai pembawa standar untuk analisis sains yang umumnya jauh lebih radikal daripada yang diproklamirkan dalam iklan untuk sosiologi sains anti-Mertonian Inggris. Kuhn mungkin menjadi pria untuk semua sosiologi musim sains, dia tampaknya sangat cocok untuk revisionisme neo-Mertonian (Restivo, 2015).

Selain itu, ilmu pengetahuan selama ini diposisikan sebagai sesuatu yang bebas nilai, harus independen, dan empiris. Pandangan ini kemudian ditolak Thomas Kuhn yang memahami ilmu pengetahuan tidak bisa terlepas dari "paradigma". Suatu paradigma berisi suatu pandangan yang dapat dipengaruhi oleh latar belakang ideologi, relasi kuasa (otoritas), dan fanatisme mendasar tentang apa yang menjadi inti persoalan suatu ilmu. Sehingga, tidak ada satu ilmu pengetahuanpun yang hanya bisa dijelaskan dengan satu teori yang dianggap lebih kuat, terlebih hanya diperolah melalui pembuktian empiris.

Bagaimanapun, gugatan atas penyimpangan (anomali) ilmu pengetahuan akan selalu ada secara terus menerus. Anomali terjadi pada saat teori tidak dapat menjawab atau menjelaskan sebuah fenomena, sehingga muncullah kebenaran baru. Begitu pula setelah diketemukan kebenaran baru, siapapun tidak bisa menyalahkan kebenaran lama yang digunakan pada masa lalu, karena itu, sebuah teori dianggap benar pada masanya. Begitu pula teori baru yang dianggap benar pada masa sekarang belum tentu akan dianggap benar pada masa yang akan datang.

Penelitian sebelumnya: Jurnal (Percival, 2013) ini meneliti penerapan untuk sejarah linguistik Thomas Kuhn konsepsi sejarah sains. Ini menyimpulkan bahwa gagasannya tentang REVOLUTION, dipinjam dari sejarah non-sains, bisa diterapkan ke sejarah ilmu bahasa; tetapi hal yang sama tidak berlaku untuk gagasan kunci lainnya, PARADIGM. Itu kepemilikan paradigma, menurut Kuhn, adalah yang membedakan ilmu-ilmu keras dari bidang humaniora dan ilmu sosial yang belum mencapai ilmiah kematangan. Kuhn menganggap paradigma sebagai (1) 
dihasilkan dari ilmiah yang luar biasa pencapaian pada bagian dari inovator tunggal, dan (2) persetujuan persetujuan seragam di antara semua anggota disiplin. Jika kedua persyaratan ini ada di mana-mana terpenuhi, konsep tersebut tidak dapat diterapkan baik pada sejarah atau keadaan saat ini ilmu bahasa. Keberatan serius juga dapat diajukan ke fitur lain dari teori Kuhn, seperti pandangan bahwa menggeser kesetiaan dari satu paradigma ke paradigma lain adalah sebagian besar proses irasional. Makalah ini merekomendasikan, kemudian, bahwa ahli bahasa meninggalkan teori.

Jurnal (Thomas S. Kuhn, 1976) These remarks should supply a fuller sense of the depth of my pleasure in Dr Sneed's formalism and in Professor Stegmiller's use of it. Even where we disagree, interaction results in significant clarification and extension of at least my own viewpoint. It is not, after all, a large step from Sneed's talk of 'different mathematical structure' or of 'different concepts' to my talk of 'seeing things differently' or of the gestalt switches that separate the two ways of seeing. Sneed's vocabul? ary gives promise of a precision and articulation impossible with mine, and I welcome the prospect it affords. But, with respect to the comparison of incompatible theories, it is entirely a prospect of things to come. Having insisted, in the first paragraph of this paper, that Sneed's new formalism makes important new territory accessible to analytic philosophy of science, I hope, in this closing section, to have indicated the part of that territory which most urgently requires exploration. Until it occurs, the Sneed formalism will have contributed little to the understanding of scientific revolutions, something I fully expect it will be able to do.

Jurnal yang diteliti oleh (Spruiell, 1983) ini menelusuri perkembangan penggunaan istilah teknis "paradigma" T. S. Kuhn. Ini mempertanyakan penggunaan longgar oleh psikoanalis. Namun, Kuhn berkembang dan lebih eksplisit pengertian paradigma dapat digunakan oleh psikoanalisis untuk mendapatkan perspektif untuk memeriksa struktur dan fungsinya sendiri. Dalam penelitian ini penulis akan menguraikan pemikiran thomas khun Teori Revolusi Paradigma.

\section{METODE PENELITIAN}

Penelitian ini menggunakan metode kepustakaan. Penelitian perpustakaan adalah pengungkapan argumentatif dari sumber data dalam bentuk studi (Syaodih, 2010). Sumber data penelitian ini adalah dalam bentuk buku yang berkaitan dengan pemikiran thomas khun teori revolusi paradigma. Sumber lain adalah temuan penelitian, hasil diskusi, jurnal, dan sebagainya. Bahan pustaka kemudian dibahas dan dianalisis secara kritis dan mendalam untuk mendukung proposisi dan gagasan yang ada dari berbagai referensi. Pengumpulan data dalam penelitian ini menggunakan teknik dokumentasi, pencarian data atau teori yang relevan dengan pertanyaan penelitian, yaitu; Bagaimana pemikiran thomas khun dengan teori revolusi paradigma dalam bentuk catatan, buku, temuan penelitian, artikel ilmiah, 
jurnal dan sebagainya. Setelah data terkumpul maka data dianalisis. Metode analisis yang digunakan adalah analisis konten dan analisis deskriptif.

\section{PEMBAHASAN}

Filosof yang dikenal dengan jargon "Revoluis Sains" ini bernama lengkap Thomas Samuel Khun. Thomas Kuhn lahir pada 18 Juli 1922 di Cincinnati, Ohio, Amerika Serikat. Khun hidup bersama seorang istri bernama Jehane R. Khun dan dua orang puterinya yaitu Sarah Khun di Massachussets dan Elizabeth Khun di Los Angeles serta seorang putera yang bernama Nathaniel S. Khun di Arlington. Selain itu Khun juga hidup bersama saudaranya Roger S. Khun di Bethesda serta empat cucunya , Emma Khun Lachange, Samuel Khun Lachange, Gabrielle Gui-Ying Khun dan Baenjamin Simon Khun (Watloly, 2001).

Sekali lagi disini posisi metodologis Kuhn mencerminkan sifat kepribadian. Meskipun dia punya banyak kenalan dan beberapa hubungan yang hangat, dia tidak mudah berteman dan selalu terkejut dengan ekspresi kasih sayang dari kolega. Contoh yang menyentuh terjadi ketika dia menanggapi simposium ramah yang diadakan untuk menghormatinya dan tentangnya bekerja pada tahun 1990 di MIT. "Ketika saya mencapai podium, saya tidak yakin saya bisa berbicara .... Setelah konferensi, istri saya berkata kepada saya bahwa saya tidak akan pernah sama lagi”. Pada kesempatan perpisahan lain, ketika Kuhn akan meninggalkan Berkeley ke Princeton, the History of Science Dinner Club yang dipimpin oleh Herbert M. Evans mengungkapkan rasa sayangnya dan rasa terima kasih "ke arahnya. Risalah catatan akhir pertemuan" dia sangat tersentuh dan juga benar-benar terkejut oleh ungkapan ini [dan] ... mengalami kesulitan besar untuk memanfaatkan yang terbaik bagian penting dari perasaannya menjadi kata-kata" (Heilbron, 1998).

Kuhn menerima banyak penghargaan akademik seperti jabatan dosen bergengsi, sepuluh atau lebih gelar kehormatan, dan keanggotaan dalam masyarakat yang terhormat, terutama Akademi Ilmu Pengetahuan Nasional, yang sebelumnya bukan, dan sekali lagi bukan, rumah bagi sejarawan dan filsuf. Selama awal karirnya, ia aktif dalam History of Science Society, yang ia layani sebagai presiden dari tahun 1968 hingga 1970; pada tahun 1982 ia menerima penghargaan tertinggi Society, Medali Sarton. Kemudian dia mengalihkan perhatiannya ke Philosophy of Science Association, yang kepresidenannya dia pegang pada tahun 1989 dan 1990 (Heilbron, 1998).

Thomas Khun meninggal pada tanggal 17 Juni 1996 di Cambridge, Massachusetts USA. Thomas Kuhn lahir dari pasangan Samuel L. Kuhn, seorang insinyur industri (Lubis, 2015). Dalam perjalanan pendidikannya Thomas Kuhn menyelesaikan studi doktornya dalam ilmu Pasti alam di Harvard pada tahun 1949 dan juga pernah menimba ilmu di University of California di Berkeley. Beliau kemudian diterima di Harvard sebagai asisten profesor pada pendidikan umum dan 
sejarah ilmu. Pada tahun 1956, Kuhn menerima tawaran kerja di Universitas California, Berkeley sebagai dosen dalam bidang sejarah sains. Pada tahun 19641979 Kuhn mengajar di Universitas Princeton dan mendapat gelar Guru Besar (Professor). Sedangkan dari tahun 1979-1991 ia bertugas di Massachusetts Institute of Technology dan dianugerahi gelar Professor untuk yang kesekian kalinya. Pada akhir masa hidupnya Kuhn menderita penyakit kanker dan akhirnya meninggal pada umur 73 tahun (Muslih, 2016).

Kuhn yang dikenal sebagai seorang fisikawan Amerika dan filsuf menulis secara ekstensif tentang sejarah ilmu pengetahuan dan mengembangkan gagasan penting dalam sosiologi dan filsafat ilmu. Salah satu karyanya yang amat terkenal dan mendapatkan sambutan dari para filsuf ilmu dan para ilmuan pada umumnya yaitu "The Structure of Scientific Revolution" yang terbit pada tahun 1962. Generalisasi deskriptif saya terbukti untuk teori itu justru karena mereka juga dapat diturunkan darinya, sedangkan pada pandangan lain tentang sifat ilmu pengetahuan mereka merupakan perilaku aneh. Lingkaran argumen itu, saya pikir, tidak menang. Konsekuensi dari sudut pandang yang sedang dibahas tidak habis oleh pengamatan yang menjadi sandarannya pada awalnya. Bahkan sebelum buku ini pertama kali diterbitkan, saya telah menemukan bagian dari teori yang disajikannya alat yang berguna untuk mengeksplorasi perilaku ilmiah dan pengembangan (Thomas S. Kuhn, 1962).

Dapat dibayangkan bahwa gagasan tentang paradigma sebagai pencapaian konkret, sebuah eksperimen, adalah kontribusi kedua. Buku ini menjadi karya yang monumental dikarenakan berisi tentang sejarah dan filsafat ilmu pengetahuan dengan konsep dan teori besarnya tentang paradigma dan revolusi ilmu dan menjadi rujukan utama para ilmuwan tahun 60-an hingga perkembangan dunia keilmuan kontemporer. Hingga dalam klasifikasi sejarah filsafat ilmu sering dikategorikan sebagai sebuah corak filsafat ilmu baru, dimana di dalamnya juga terdapat tokoh lain seperti Imre Lakatos dan Paul Feyerabend (Muslih, 2016).

Kuhn's contributionw a 'sociology of knowledge', that is, an explanationo f the genesios of knowledgiet, would requirean analysis of the relations between science and society, between science and different parts and groups within society, and between different parts and groups within science; and it would require a theory of cognition and of truth. A theory of cognition and truth implies both an explanation of why actors come to believe in something for good reasons, and an analysis of whethers uch beliefs are correct. Kuhn approachest he former at least in showing that the process of selection between scientific theories is unequivocably social and the criteria used are 'context dependent' (Urry, 1973).

Karya Kuhn menarik banyak kalangan karena dia menggunakan model politik dalam menjelaskan perkembangan sains. Kuhn memakai istilah revolusi untuk menggambarkan proses pengembangan dalam sains dan menekankan wacana 
pemberian alternatif teori baru dalam memandang sains yang berlaku. Pandangan Kuhn ini menajadikannya revolusioner terhadap arah pemikiran pembaharuan teori keilmuan terutama dalam bidang filsafat ilmu (Sabila, 2019).

Di antara karya-karya yang telah ditulis oleh Khun adalah:

1. The Copernican Revolution: Planetary Astronomy in the Development of western Thought, Cambride Mass: Harvard University Press. 1957

2. The structure of scienttific Revolution, Chicago: University Of Chicago Press (1970, 2nd edition, with postscript), 1962/1970.

3. The essential tension, elected studies in scrintific traditional and change. Chicago: University Of Chicago Press, 1997

4. Black-Body Theory and the quantum discontinuity, oxford: clarendon press (2nd edition Chicago: University Of Chicago Press) 1998.

5. The road since structure, "edited by james conant and john haugeland", Chicago: University Of Chicago Press, 2000 (Putra, 2015).

\section{Sumbangan Paradigma Thomas S. Kuhn}

Ilmu pengetahuan bukanlah perolehan pengetahuan yang stabil dan kualitatif yang digambarkan dalam buku-buku teks. Sebaliknya, ini adalah serangkaian selingan damai yang diselingi oleh revolusi kekerasan intelektual. Selama selingan itu, para ilmuwan dipandu oleh serangkaian teori, standar, dan metode yang oleh Kuhn disebut sebagai "paradigma". Paradigma adalah dasar dari tradisi penelitian; ia mendefinisikan masalah mana yang menarik dan mana yang tidak relevan. Selama interaksi dengan paradigma, yang disebut periode "ilmu pengetahuan normal" oleh Kuhn, para ilmuwan pada dasarnya memecahkan teka-teki yang dihasilkan oleh paradigma tersebut. Studi mekanika setelah Principia Newton adalah salah satu contoh dari periode ilmu normal; astronomi setelah Copernicus adalah hal lain. Alam terlalu kompleks untuk dieksplorasi secara acak; paradigma adalah rencana eksplorasi yang menunjukkan teka-teki dan jaminan bahwa mereka dapat larut. Itulah alasan kemajuan pesat ilmu-ilmu alam berbasis paradigma dibandingkan dengan mereka yang berada dalam tahap persiapan paradigma seperti ilmu social (Wade, 1977).

Thomas S. Kuhn meruntuhkan anggapan yang telah diterima tentang ilmuwan sebagai pencari kebenaran dan interogator alam dan realitas yang heroik, berpikiran terbuka dan bebas kepentingan, "demikian disimpulkan Zianuddin Sardar dalam buku kecilnya Thomas Kuhn dan Perang Ilmu (Zianuddin Sardar, 2002). Pengamatan ini tepat, karena Kuhn melihat bahwa para ilmuwan menggeluti ilmu mereka secara membosankan dengan di satu pihak mengembangkan ilmu dan riset berdasarkan metode-metode yang sudah ada dan baku, sementara di lain pihak berusaha semakin memperluas jangkauan metodemetode tersebut. Dengan kata 
lain, para ilmuwan bergerak dalam kerangka metode ilmiah proses observasi, deduksi dan konklusi yang diidealkan untuk mencapai objektivitas dan universalisme ilmu pengetahuan. Dalam arti itu sebetulnya ilmuwan bukanlah para pahlawan pencari kebenaran, tetapi para pemecah teka-teki alam berdasarkan model tertentu yang sudah disepakati bersama (Jena, 2012).

Menurut Kuhn, periode krisis mempolarisasi persaingan pihak dalam revolusi politik dan revolusi ilmiah. Di keduanya kasus, pembela orde lama menghadapi advokat orde baru. Di tahap ini, perbedaan antara kelompok yang bersaing tidak lagi bisa diselesaikan dengan bantuan strategi politik normal atau, dalam kasus sains, metode normal dan logika. Istirahat tata kelola kelembagaan turun. Kelompok yang bersaing tidak dapat menyepakati cara untuk mencapai dan mengevaluasi perubahan dalam konteks kelembagaan yang ada, dan mereka menolak mode resolusi konflik suprainstitutional. Hasilnya adalah jalan lain untuk persuasi massa dan kemudian memaksa. Dalam revolusi ilmiah, Kuhn berpendapat, proses pemilihan paradigma akhirnya tercapai berdasarkan standar tertinggi: persetujuan dari ilmiah masyarakat. Sifat ekstrainstitusional dari revolusi dalam politik dan dalam sains, Kuhn berpendapat, adalah aspek kunci dari evolusi institusi (Thomas S. Kuhn, 1976).

Struktur revolusi ilmiah menggairahkan imajinasi para sejarawan yang bekerja terutama karena banyak yang dikatakan tentang komunitas ilmiah tampaknya berlaku begitu mencolok untuk komunitas-komunitas lain. David H. Fischer menegaskan bahwa Kuhn "relevan dengan semua bidang" sejarah, dan sejumlah manifes telah mengumumkan penerapan Kuhn pada sejarah intelektual umum dan subdisiplinnya. Dalam praktiknya, istilah Kuhn telah digunakan secara eksplisit oleh para sejarawan seni, agama, organisasi politik, pemikiran sosial, dan kebijakan luar negeri Amerika, selain penggunaannya yang lebih dapat diprediksi oleh para sejarawan ilmu sosial dan ilmu alam (Hollinger, 1973).

Karya Kuhn yang berjudul "The Structure of Scientific Revolutions" banyak mengkritik tajam tentang pandangan positivisme dan falsifikasi Popper. Thomas Khun dalam sejarah filsafat Barat, terutama pasca berlalunya masa positivisme Auguste Comte yang diikuti filosof di lingkaran positifisme dan falsifikasi Karl Popper. Jika positivisme membagi pengetahuan menjadi dua yaitu meaningfull (meliputi ilmu yang empiris-induktif dan dianggap pasti) dan meaningless (termasuk didalamnya agama, metafisika dan seni), dalam makna yang sama, Popper mengenalkan istilah baru yaitu science untuk yang pertama dan pseudoscience untuk yang kedua. Berbeda dengan positivisme Popper meyakini bahwa keduanya meaningfull (Walker, 2010). 
Tabel perbedaan pemikiran antara Auguste Comte, Popeper dan Thomas Khun

(Murabbi, 2014)

\begin{tabular}{|c|c|c|c|c|}
\hline $\begin{array}{l}\text { Aspek yang } \\
\text { dibandingkan }\end{array}$ & $\begin{array}{l}\text { Auguste } \\
\text { Comte } \\
\text { Positivisme } \\
\end{array}$ & Popper & $\begin{array}{l}\text { Titik Temu } \\
\text { Positivisme dan } \\
\text { Popper }\end{array}$ & Kuhn \\
\hline Uji Teori & Verifikasi & Falsifikasi & \multirow{4}{*}{$\begin{array}{l}\text { tegas } \\
\text { membedakan } \\
\text { antara observasi } \\
\text { dan teori } \\
\text { pertumbuhan } \\
\text { pengetahuan } \\
\text { bersifat liner } \\
\text { akumulatif } \\
\text { (bertumpuk) dan } \\
\text { evolutif } \\
\text { terminologi } \\
\text { ilmiah harus } \\
\text { tepat yang } \\
\text { ilmu obyektif bisa } \\
\text { dicapai }\end{array}$} & Tidak membahas \\
\hline Macam ilmu & $\begin{array}{l}\text { Meaningfull } \\
\text { meaningless }\end{array}$ & $\begin{array}{l}\text { Science- } \\
\text { pseudo } \\
\text { science }\end{array}$ & & $\begin{array}{lr}\text { pembedaan } & \text { yang } \\
\text { jelas } & \text { antara } \\
\text { observasi } & \text { dengan } \\
\text { teori. } & \end{array}$ \\
\hline Fondasi Ilmu & Ada & $\begin{array}{l}\text { Tidak Ada } \\
\text { karena } \\
\text { semua ilmu } \\
\text { rentan salah }\end{array}$ & & $\begin{array}{l}\text { ilmu tidaklah } \\
\text { akumulatif } \\
\text { melainkan } \\
\text { revolusioner }\end{array}$ \\
\hline $\begin{array}{l}\text { Metode } \\
\text { memperoleh }\end{array}$ & Induksi & Deduksi & & $\begin{array}{l}\text { konsep-konsep } \\
\text { ilmiah tidak harus } \\
\text { pasti } \\
\text { Konteks justifikasi } \\
\text { tidak bisa } \\
\text { dipisahkan dari } \\
\text { konteks penemuan } \\
\text { karena ilmu bersifat } \\
\text { historis } \\
\text { Ilmu yang obyektif } \\
\text { hanya ilus }\end{array}$ \\
\hline
\end{tabular}

Dalam hal ini, Thomas Kuhn berpendapat bahwa baik Auguste Comte dan Popper terlalu sibuk dengan hal-hal yang menurutnya termasuk dalam tradisi penyelesaian teki-teki (puzzle-solving tradition) dan melupakan aspek penting dalam ilmu pengetahuan, yaitu paradigma. Istilah paradigma dan revolusi ilmiah akhirnya menjadi karakteristik yang melekat pada corak pemikiran Thomas Kuhn (Abid, 2015).

\section{Konsep Paradigma Revolusi Sains Thomas Kuhn}

Thomas Khun mengkritik pandangan yang mengatakan bahwa perkembangan ilmu bersifat akumulatif (bertumpuk-tumpuk). Ia mengatakan "The transition from a paradigm in crisis to a new one from which a new tradition of normal science can emerge is far from a cumulative process, one achieved by an articulation or extension of the old paradigm" (Murabbi, 2014). Menurutnya, ilmu berkembang secara revolusioner, dalam artian bahwa paradigma yang lama digantikan secara total (in whole) dengan paradigma baru yang berbeda (incompatible). Untuk membuktikannya, Khun menyusun sebuah contoh siklus ilmu pengetahuan yang di dalamnya terdapat hal yang disebutnya dengan "paradigma", komunitas ilmiah dan revolusi sains. 
Istilah "paradigma" menjadi titik tekan dalam epistimologi Thomas Khun. Ia mendefinisikannya sebagai "what the members of a scientific community share, and, conversely, a scientific community consists of men who share a paradigm", yang artinya paradigma adalah segala hal yang diterima dan ditanggung bersamasama oleh sebuah masyarakat ilmiah, dengan kata lain sebuah masyarakat ilmiah terdiri dari orang-orang yang memiliki kesamaan paradigma. Baik Normal Science maupun sains hasil revolusi yang nanti akan dijelaskan lebih lanjut adalah kegiatan yang berbasis komunitas (community-based activities) sehingga menganalisa atau bahkan membongkarnya berarti membongkar struktur masyarakat sains yang terus menerus berubah (Murabbi, 2014).

Paradigma adalah suatu pendekatan investigasi suatu objek atau titik awal mengungkapkan point of view, formulasi suatu teori, mendesign pertanyaan atau refleksi yang sederhana. Akhirnya paradigma dapat di formulasikan sebagai keseluruhan sistem kepercayaan, nilai dan teknik yang digunakan bersama oleh kelompok komunitas ilmiah (Nurkhalis, 2012).

Paradigma didefinisikan sebagai pandangan dasar tentang apa yang menjadi pokok bahasan yang seharusnya dikaji oleh disiplin ilmu pengetahuan, mencakup apa yang seharusnya ditanyakan dan bagaimana rumusan jawabannya disertai dengan interpretasi jawaban. Paradigma dalam hal ini adalah konsesus bersama oleh para ilmuan tertentu yang menjadikannya memiliki corak yang berbeda antara satu komunitas ilmuan dan komunitas ilmuan lainnya. Varian paradigma yang berbedabeda dalam dunia ilmiah dapat terjadi karena latar belakang filosofis, teori dan instrumen serta metodologi ilmiah yang digunakan sebagai pisau analisisnya (Upe, 2010). Thomas Kuhn dalam buku The Structure of Scientific Revolution menjelaskan:

"By choosing it, I mean to suggest that some accepted examples of actual scientific practice-examples which include law, theory, application and instrumentation together-profide models from which spring particular coherent traditions of scientific research" (Thomas S Kuhn, 1962).

Berdasarkan ungkapan diatas Kuhn menjelaskan paradigma sebagai beberapa contoh praktik ilmiah aktual yang diterima. Termasuk contohnya adalah hukum, teori, aplikasi, dan instrumen yang merupakan model yang diterima bersama dan menjadi sumber tradisi khusus dalam penelitian ilmiah.

Kuhn menilai paradigma dapat diformulasikan sebagai keseluruhan sistem kepercayaan, nilai teknik yang digunakan bersama oleh kelompok komunitas ilmiah (Ritzer, 2004). Paradigma identik sebagai sebuah bentuk atau model untuk menjelaskan suatu proses ide secara jelas. Paradigma sebagai seperangkat asumsiasumsi teoritis umum dan hukum-hukum serta teknik-teknik aplikasi yang dianut secara bersama oleh para anggota suatu komunitas ilmiah (Heriyanto, 2003). Konstitusi kebenaran sains tidak tergantung pada pilihan ilmiah (scientific) akan 
tetapi memiliki kriteria yaitu; pertama, imprecise (ruang perbedaan pendapat tentang sejauh mana mereka berpegang teguh). Kedua, tidak ada agreement tentang bagaimana para ilmuan menentang satu sama lainnya khususnya ketika terjadi perbedaan ilmiah terhadap sains baru. Ia menyebutnya dengan "rational men to disagree".Gambaran ini dipandang sebagai transformation of vision. Penerimaan sebuah paradigma baru sering membutuhkan sebuah redefinisi dari ilmu yang sesuai (corresponding). Paradigma baru akan tetap bersifat relatif sejauh berdasarkan keyakinan dan selera intelektual masing-masing kelompok ilmuan (saintis) (Hasbullah, 2000).

Paradigma ilmu menurut Kuhn adalah suatu kerangka teoritis, atau suatu cara memandang dan memahami alam, yang telah digunakan oleh sekelompok ilmuwan sebagai cara pandang dunia (worldview) nya. Fungsi dari paradigma ilmu adalah sebagai lensa yang melaluinya ilmuwan dapat mengamati dan memahami masalahmasalah ilmiah dalam bidang masing-masing dan jawaban-jawaban ilmiah terhadap masalah-masalah tersebut. Maka paradigma ilmu dapat dianggap sebagai skema kognitif yang dimiliki bersama. Skema kognitif tersebut berfungsi sebagai suatu cara untuk mengerti alam sekelililng dan memahami alam ilmiah. Terdapat beberapa ciri dari Paradigma, diantaranya:

a. Paradigma Identik Sebagai Worldview

Paradigma identik sebagai sebuah bentuk atau model untuk menjelaskan suatu proses ide secara jelas. Penerimaan sebuah paradigma baru sering membutuhkan sebuah redefinisi dari ilmu yang sesuai (corresponding). Paradigma baru akan tetap bersifat relatif sejauh bedasarkan keyakinan dan selera intelektual masing-masing kelompok ilmuan (saintis) (Hasbullah, 2000). Patton mendefinisikan pengertian paradigma untuk memberikan kejelasan terhadap teori paradigma Kuhn yaitu:

"A paradigm is a world view, a general perspective , a way of breaking down the complexity of the real world. As such, paradigms are deeply embedded in the socialization of adherents and practitioners: paradigms tell them what is important, legitimate, and reasonable. Paradigms are also normative, telling the practitioner what to do without the necessity of long existential or epistemological con-sideration. But it is this aspect of paradigms that constitutes both their strength and their weakness-their strength in that it makes action possible, their weakness in that the very reason for action is hidden in the unquestioned assumptions of the paradigm"(Patton, 1990).

Paradigma dipahami sama dengan world view (pandangan dunia), general perspective (cara pandang umum), atau "way of breaking down the complexity" (cara menguraikan kompleksitas). Makna worldview sebagai kepercayaan, perasaan dan apa-apa yang terdapat dalam pikiran orang yang berfungsi sebagai 
penggerak bagi keberlangsungan dan perubahan sosial dan moral. World view diartikan sebagai pandangan manusia terhadap dunia realitas. Penekanannya pada fungsi worldview sebagai perubahan sosial dan moral. Sehingga worldview diartikan sebagai sistem kepercayaan yang integral tentang hakekat diri manusia, realitas, dan makna eksistensial. Setiap aktivitas manusia akan mencari dan menguraikan ke dalam worldview (Acikgence, 1996).

b. Paradigma Bersifat Shifting

Konsep paradigma shifts membuka kesadaran bersama bahwa para pengkaji ilmu pengetahuan itu tak akan selamanya mungkin bekerja dalam suatu suasana "objektivitas" yang mapan, yang bertindak tak lebih tak kurang hanya sebagai penerus yang berjalan dalam suatu alur progresi yang linier belaka. Menurut Kuhn, para saintis bekerja dalam komunitas tertentu mampu menjelaskan keberhasilan yang menakjubkan dari sebuah sains masyarakat ilmiah adalah instrumen sangat efisien untuk memaksimalkan jumlah dan ketepatan masalah diselesaikan melalui Paradigma shifts (pergeseran paradigma). Ketika paradigma berubah disebabkan adanya shift (pergeseran) biasanya signifikan determinan dengan kriteria legitimasi antara masalah dan solusi yang dimunculkan. Ketika para ilmuwan menemukan anomali yang tidak dapat dijelaskan oleh yang diterima secara universal Paradigma di mana kemajuan ilmiah telah dibuat. Paradigma itu, dalam pandangan Kuhn, bukan semata-mata teori saat ini, tetapi seluruh pandangan dunia di mana ia ada, dan semua implikasi yang menyertainya (Orman, 2016).

c. Paradigma menjawab puzzle solving

Paradigma menunjukan sejenis unsur puzzle solving (pemecahan teka-teki) yang kongkrit yang jika digunakan sebagai model, pola, atau contoh dapat menggantikan kaidah-kaidah yang secara eksplisit menjadi dasar bagi pemecahan permasalahan dan teka-teki normal science yang belum tuntas. Kuhn menentang eksistensi realitas sains. Sains yang dikaji akan mendeteksi paradigma baru berkembangkan berdasarkan prediksi yang akurat, tetapi para ahli sains tidak memiliki alasan kuat untuk percaya bahwa prediksi yang akurat terkadang tidak sesuai dengan apa yang ada dalam realitas. Kuhn melihat bahwa alasan satu paradigma bertahan sedangkan yang lain mati karena salah satunya dapat memecahkan puzzle (teka-teki) yang lebih baik. Sains tidak ditarik mengarah kepada kebenaran tetapi sains didorong maju untuk memecahkan permasalahan puzzle (teka-teki) selama dalam tahap normal science, artinya suatu teori atau temuan yang masih berlaku sehingga suatu sains tersebut terus live belum terdeteksi temuan baru pada suatu objek yang sama. Normal science meletakkan mop up (penghentian) terhadap persoalan yang tidak terjawab oleh kerangka teori baru. Normal science sebagai tujuan, pada suatu kejadian muncul inkonsistensi dengan paradigma yang berlaku (the current paradigm) (Nurkhalis, 2012). 
d. Paradigma dipahami sebagai revolusi ilmiah

Perkembangan sains bukanlah terjadi secara kumulatif tetapi terjadi secara revolusi. Pendekatan revolusionistis yang merupakan inti dari konsep paradigma adalah bentuk progresi kebebasan secara linier yang kian meningkat dan berpuncak pada masa kini (Ziauddin Sardar, 2002).

Revolusi ilmiah merupakan perubahan drastis yang terjadi dalam tahapan perkembangan ilmu pengetahuan. Revolusi sains muncul disebabkan ada anomali yang dirasakan semakin parah dalam riset dan paradigma yang dijadikan referensi riset tidak dapat menyelesaikan krisis. Paradigma yang lama akan diganti seluruh atau sebagiannya dengan paradigma baru yang bertentangan dalam episode perkembangan nonkumulatif pada revolusi sains. Munculnya revolusi sains tidak semerta-merta mudah, karena ada kalanya sebagian ilmuwan atau masyarakat tidak mau menerima paradigma baru tersebut, sehingga menimbulkan masalah legitimasi paradigma yang lebih definitif (Almas, 2018). Skema adanya paradigma lama hingga sampai terbentuknya revolusi ilmiah pada paradigma baru adalah sebagai berikut:

Tahapan Revolusi Ilmiah (Lubis, 2015)

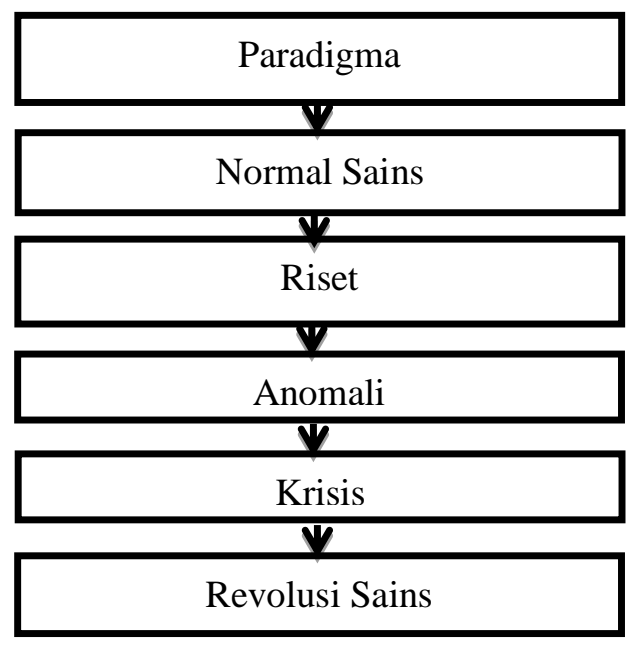

Kegiatan ilmiah dalam masa sains normal dibimbing oleh paradigma yang memberikan kesempatan para ilmuwan untuk menjabarkan dan mengembangkannya secara terperinci dan mendalam. Selama menjalankan riset ilmuwan akan menemukan berbagai fenomena yang tidak dapat diterangkan dengan teorinya, hal inilah yang disebut dengan anomali. Anomali-anomali ini apabila semakin menumpuk dan kualitasnya semakin meninggi maka akan menimbulkan krisis. Adanya krisis ini akan menimbulkan pertanyaan terhadap paradigma, karena diposisi ini ilmuwan sudah dinyatakan keluar dari sains normal. Solusi dari situasi ini biasanya para ilmuwan akan kembali pada cara ilmiah yang lama sambil memperluas cara-cara tersebut dan mengembangkan paradigma tandingan yang 
dapat memecahkan masalah dan dapat digunakan untuk riset berikutnya. Cara terakhir inilah yang berhasil akan melahirkan revolusi ilmiah (Zubaedi, 2007).

Thomas Kuhn mengemukakan bahwa sains normal dapat memungkinkan kita untuk memecahkan teka-teki yang keberadaannya validitas dari paradigma harus diasumsikan. Jadi singkatnya, dia pikir pekerjaan itu dalam paradigma (matriks disiplin qua) hanya mungkin jika paradigma itu diterima begitu saja. Fungsi paradigma sangat baik sampai para ilmuwan dalam upaya kolaboratif mereka memiliki teka-teki yang tidak sesuai. Disinilah anomali terjadi. Krisis adalah apa yang dibutuhkan. Para ilmuwan mulai mempertanyakan asumsi dasar dan paradigma yang berbeda muncul. Ini diikuti oleh bentrokan paradigma yang saling bertentangan dan tidak dapat dibandingkan, dengan kemenangan akhir satu paradigma. Dengan demikian, revolusi ilmiah telah terjadi dan para ilmuwan mengalami perubahan gestalt. Mengikuti revolusi sekali lagi adalah tahap sains yang normal. Kuhn berpendapat bahwa proses siklus ini berlangsung terus menerus (Orman, 2016).

Kuhn dengan mendasarkan pada sejarah ilmu, berpendapat bahwa terjadinya perubahan-perubahan yang berarti tidak pernah terjadi berdasarkan upaya empiris untuk membuktikan salah (falsifikasi) suatu teori atau itern, melainkan berlangsung melalui revolusi-revolusi ilmiah. Dengan kata lain, Kuhn berdiri dalam posisi melawan keyakinan yang mengatakan bahwa kemajuan ilmu berlangsung secara kumulatif. Ia mengambil posisi alternatif bahwa kemajuan ilmiah pertama-pertama bersifat revolusioner. Secara sederhana yang dimaksud dengan revolusi ilmiah oleh Kuhn adalah segala perkembangan nonkumulatif yakni paradigma yang terlebih dahulu ada (lama) diganti keseluruhan ataupun sebagian dengan yang baru (Munir, 2004).

Skema Revolusi Ilmiah (Munir, 2004)

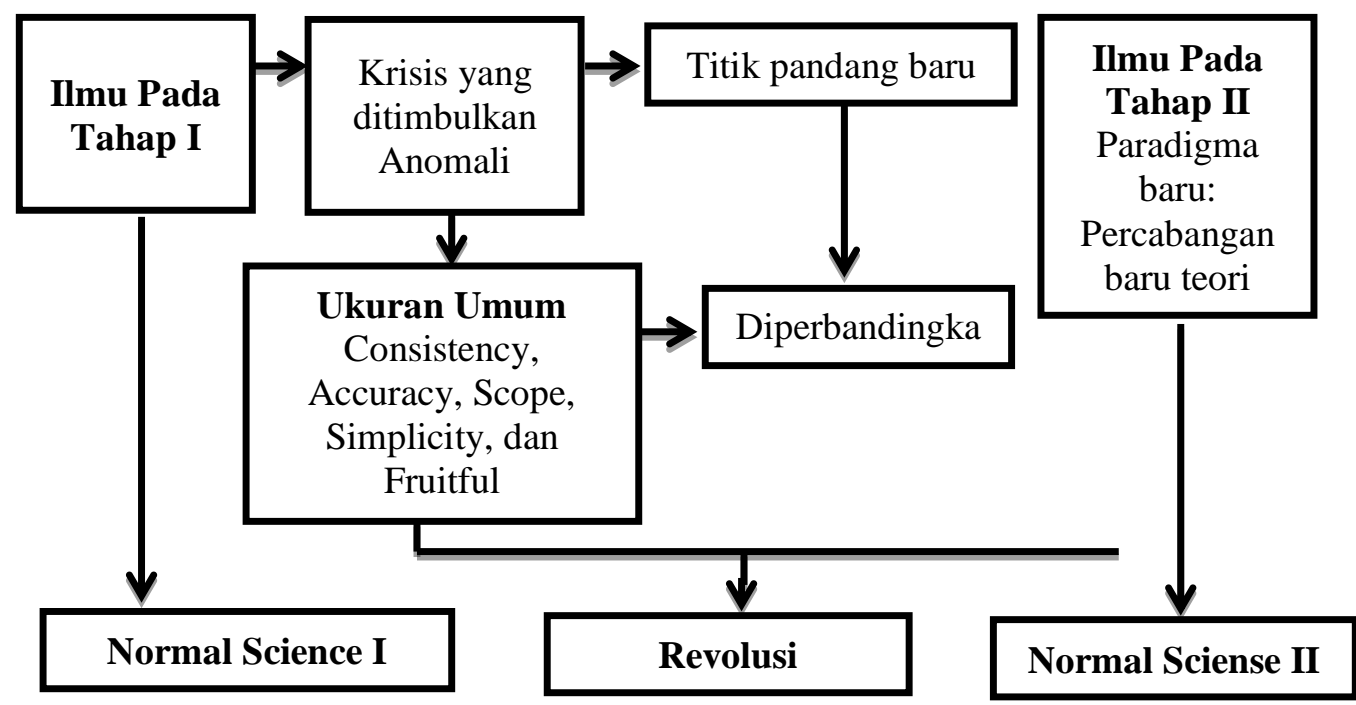


Sains Normal merupakan penyelidikan dalam usaha menafsirkan alam ilmiah yang dibuat oleh suatu komunitas ilmiah melalui paradigma ilmiahnya. Sedangkan krisis merupakan kepastian bahwa kelakuan pada fase sains normal akan mengarah pada situasi yang berbahaya shingga perlu adanya pengembangan (Riyanto, 2011). Transformasi paradigma juga dapat disebut sebagai revolusi sains dan perkembangan paradigma dari transisi yang berurutan melalui revolusi disebut juga dengan sains yang telah matang. Contohnya adalah teori cahaya dalam ilmu fisika yang pada awalnya dinyatakan sebagai foto atau maujud mekanis kuantum yang memperlihatkan beberapa karakteristik gelombang dan beberapa karakteristik partikel. Teori ini hanya berumur setengah abad untuk dijadikan landasan riset selanjutnya, dan kemudian muncul teori baru dari Newton yang menjelaskan bahwa cahaya adalah partikel yang sangat halus. Teori Newton banyak diterima oleh pemraktik sains optika sebelum kemudian muncul teori baru lagi dari Young dan Fresnel pada awal abad ke 19 yang lebih unggul. Teori ini menyatakan bahwa cahaya adalah gerakan gelombang universal yang kemudian dikembangkan oleh Planck dan Einsten (Thomas Samuel Kuhn, 2002).

Paradigma: Pola yang diuraikan di atas paling baik dipahami dan dijelaskan oleh adanya paradigma. Arti kunci dari 'paradigma' adalah contoh: contoh teladan dari pemecahan teka-teki dalam disiplin itu yang menyediakan konteks dan model untuk memecahkan teka-teki di masa depan. Paradigma juga digunakan untuk merujuk pada matriks disiplin, seperangkat komitmen dibagikan oleh praktisi dari bidang ilmiah tertentu, termasuk kosakata khusus dan teknik eksperimental yang mapan, serta klaim teoritis yang diterima. Komitmen pusat dari matriks disiplin adalah untuk contoh bersama; dengan menyetujui pada contoh, lapangan dengan demikian menyetujui komponen lain dari matriks. Eksemplar ditransmisikan dan ditanamkan oleh pelatihan ilmuwan muda. Pelatihan dengan eksemplar memungkinkan para ilmuwan untuk melihatnya dunia dengan cara tertentu yang memungkinkan mereka untuk memecahkan masalah ilmiah dengan cara yang dianalogikan dengan yang ada di dalam contoh. Ilmu pengetahuan normal dengan demikian dibangun di atas dan dibangun oleh para eksemplar. Krisis terjadi ketika sains yang dimodelkan pada contoh gagal menjawab teka-teki utama. Revolusi terjadi ketika eksemplar digantikan oleh eksemplar baru; revisi terhadap contoh seperti itu akan membawa perubahan lain pada matriks disipliner (Meyers et al., 2020).

Contoh Tabel Revolusi Ilmiah Teori Cahaya

(Thomas Samuel Kuhn, 2002)

\begin{tabular}{lllll}
\hline No & Ilmuan & Periode & Teori & \\
\hline $\mathbf{1}$ & Ilmuan Awal & Awal & Foton & \\
$\mathbf{2}$ & Newton & Pertengahan & Praktikel Halus & \\
$\mathbf{3}$ & Young \& Fresnel & Awal abad-19 & Gerakan & Gelombang \\
\hline
\end{tabular}




\begin{tabular}{|c|c|c|}
\hline & & Transversal \\
\hline Planck \& Einstein & Abad-19 & $\begin{array}{l}\text { Pengembangan gerakan } \\
\text { gelombang transversal }\end{array}$ \\
\hline
\end{tabular}

Normal science is achieved when the discipline more or less universally accepts the dominant paradigm, which then directs the practitioner as to the key questions and appropriate methods of normal research. Normal science is a period of paradigm articulation involving the manipulation of fact and theory to expand the scope and precision and resolve ambiguities of the paradigm. Significantly, normal science is characterized by a lack of intent to uncover phenomenal or theoretical novelties. The accepted paradigm defines the appropriate problems to pursue and the procedures to be used for this pursuit, and it guarantees that solutions exist to the problems using these procedures. Normal science is puzzlesolving; when an experiment fails to produce the anticipated result, the puzzle solver, not the puzzle (paradigm), is considered inadequate. This point is important because, as is shown below, scientific revolutions are rejections of paradigms which do not make good their guarantees (Stanfield, 1974).

Revolusi sains dapat terwujud terlihat dari sejauh mana paradigma baru itu diterima oleh masyarakat sains. Hal ini tidak hanya konsensus atau kesepakatan yang sangat ditentukan oleh retorika di kalangan akademisi dan atau masyarakat sains itu sendiri (Zubaedi, 2007). Jikalau terdapat ilmuwan atau sebagian kecil ilmuwan yang tidak mau menerima paradigma baru tersebut dan ia masih bertahan dengan paradigma yang telah dibongkar dan tidak mendapat dukungan dari mayoritas masyarakat sains, maka aktivitas risetnya hanya merupakan tautologi yang tidak bermanfaat sama sekali.

\section{Pemikiran Thomas Kuhn Transformasi dalam Keilmuan Islam}

Dalam analisis Smith, tradisi kumulatif masih akan menjadi entitas yang tidak dapat dipertahankan, tetapi hal yang sama tidak akan berlaku untuk keyakinan pribadi. Menurut Smith adalah mungkin bahwa orang-orang beragama mencari realitas transenden yang sama terlepas dari ketidakterbandingan dari tradisi agama yang mereka klaim milik. Dalam hal ini, pandangan Smith tidak akan sesuai dengan pandangan Struktur tentang ketidakterbandingan, tetapi lebih suka bergabung dengan kritik Kuhn pada poin teorinya yang khusus ini. Jika ketidakterbandingan antara paradigma dianggap sebagai titik lemah dalam teori Kuhn, ia juga memiliki konsekuensi bagi perlunya revolusi untuk bergerak dari satu paradigma ke paradigma lain. Debat ini juga memiliki paralelnya dalam studi agama, paling jelas diartikulasikan oleh Comaro yang telah mempelajari konversi agama dari Agama Tradisional ke Kristen di Afrika Selatan. Mereka berpendapat bahwa pertobatan Protestan modern itu sendiri merupakan konstruksi yang jenuh secara ideologis, yang menjadikan pertobatan sebagai pilihan rasional individu di antara agama alternatif yang saling eksklusif. Pilihan seperti itu mengandaikan individualisme 
spiritual, yang merupakan konstruksi Barat, tidak diketahui oleh bagian dunia lain di mana agama pertama-tama merupakan kepentingan komunitas. Comaro berpendapat bahwa konversi di Afrika Selatan tidak tiba-tiba putus dengan masa lalu, melainkan percakapan panjang di mana orang-orang lokal menerjemahkan “... pesan penginjil ke dalam bahasa mereka sendiri relativisme budaya..." Meskipun kritik Smith dan Comaro terhadap pandangan tradisional Barat tentang konversi agama tidak sesuai dengan elemen irasional atau supra-alami dalam konversi agama, mereka mengajukan pertanyaan penting mengenai ketidakberbandingan pandangan dunia yang berbeda agama. Pertanyaan-pertanyaan yang harus dipertimbangkan dengan cara yang sama kritik terhadap teori Kuhn tentang ketidakterbandingan telah disepakati secara umum. Ini tidak berarti bahwa Kuhn semuanya salah atau bahwa pandangan Barat tradisional tentang konversi agama semuanya salah. Namun, hal itu seharusnya membuat kita memodifikasi ide Struktur tentang ketidakcocokan paradigma ilmiah, dan gagasan bahwa konversi agama selalu merupakan proses radikal dan tiba-tiba di mana satu pandangan dunia digantikan oleh cara lain yang saling eksklusif dalam mendekati dunia secara transikologis, ontologis, dan secara sosial (Drønen, 2006).

Sedangkan di dunia Islam pemikiran thomas khun mulai di transformasi ke dalam paradigma filsafat Islam ini merupakan suatu yang unik. Ditinjau dari sejarah peradaban manusia, jarang ditemukan suatu kebudayaan asing dapat ditransformasikan dan diterima oleh kebudayaan lain, terlebih dijadikan landasan dalam pemahaman filosofisnya, karena masing-masing memiliki karakteristik yang berbeda antara satu dengan yang lain.

Al-Kindi, al-Farabi, Ibnu Rusyd adalah filosof muslim yang menjadi suri tauladan kaum muslim yang banyak mengemukakan pandangan yang menarik, khususnya dalam penyebaran filsafat dan penetrasinya dalam studi-studi keislaman, sehingga para filosof muslim tersebut menghasilkan afinitas dan ikatan yang kuat antara filsafat Arab dan filsafat Yunani (Madkoer, 1986).

Selain itu, tahap perkembangan tradisi keilmuan Islam diperlihatkan dengan masuknya unsur-unsur lain dari luar, misalnya unsur-unsur budaya Perso-Semitik (Zoroastrianisme, khususnya Mazdaisme, Yahudi dan Kristen) dan budaya Hellenisme. Begitu pula dengan usaha-usaha untuk menengahi pandangan yang dikotomis antara faham Qodariyah dan Jabariyah juga menggunakan argumenargumen Hellenisme (Bakhtiar, 2010).

Kajian terhadap pemikiran Thomas Kuhn dan transformasinya ke dalam paradigma keilmuan Islam dapat dianalisa pada hal-hal berikut: (Abid, 2015)

Pertama: Pemikiran Kuhn tentang paradigma dapat difahami sebagai fondasi awal untuk menentukan landasan filosofik ilmu dan landasan teoretik ilmu pengetahuan. Wacana yang berkembang dalam paradigma terjadi secara 
dialektik dan interaktif dalam pembentukan dan penolakan terhadap suatu paradigm ilmiah. Sehingga dalam konteks pemikiran keilmuan Islam dapat dimaknai sebagai progresifitas berfikir dalam memahami paradigm ajaran Islam berdasarkan landasan normatifnya, dinamika pemikirannya, kontinuitasnya dan sensitifitasnya dalam menjawab persoalan-persoalan yang ada dalam masyarakat membutuhkan paradigma yang kuat. Arah dan tujuannya adalah menjadikan Islam sebagai agama rahmatan lil Alamin.

Kedua: Pemikiran Kuhn tentang normal science menggambarkan sebuah kondisi ketika sebuah paradigma menjadi sedemikian dominan dan digunakan sebagai indikator utama. Normal science dalam konteks pemikiran Islam didasarkan pada teori yang terdapat dalam sumber hukum Islam yang mana dalam perkembangannya tetap dapat dijadikan sebagai norma atau kaidah dan tidak ada penyimpangan dan kesulitan dalam menjalankannya dalam kehidupan praktis. Normal science dalam kajian studi Islam dapat dianalogikan dengan memahami teori-teori ajaran Islam menggunakan pendekatan teologis normatif.

Ketiga: Pemikiran Kuhn tentang anomali ialah gambaran ketidakselarasan antara kenyataan dengan paradigma-paradigma yang digunakan ilmuwan. Anomali terjadi karena paradigma pertama tidak mampu memberikan penjelasan dan menjawab terhadap persoalan yang timbul dan akhirnya terjadi penyimpangan. Anomali dalam konteks pemikiran Islam terjadi seiring dengan berkembangnya kehidupan dan perubahan zaman. Dalam hal ini terjadi suatu kondisi bahwa ajaran Islam yang berada dalam ranah teologis normatif tidak seluruhnya dapat menjawab seluruh persoalan umat Islam. Sehingga pada fase ini, kajian tentang pemikiran Islam mengalami sesuatu yang dalam istilahnya Kuhn disebut sebagai crisis.

Keempat: Revolusi Ilmu (scientific revolution) dalam pemikiran Kuhn adalah terjadinya lompatan-lompatan dan perubahan-perubahan secara drastis dan pada akhirnya akan memunculkan paradigma baru berdasarkan studi ilmiah lanjutan dan dikaji berdasarkan sudut pandang dan teknik metodologi yang lebih unggul dibanding paradigma lama dalam upaya memecahkan masalah. Revolusi ilmiah dalam konteks pemikiran Islam adalah upaya untuk melakukan perubahan secara drastis mengenai pemahaman dan interpretasi ajaran Islam untuk dapat menjawab persoalan yang ada dalam masyarakat sebagai akibat dari perkembangan zaman. Seiring dengan perkembangan zaman, problematika masyarakat juga selalu berkembang dan berubah. Sehingga hukum Islam otomatis ikut berubah selaras dengan perubahan waktu dan ruang yang melingkupi (Rahman, 1987). 
Transformasi hukum Islam tersebut mengacu pada tiga dimensi, yaitu dimensi pemeliharaan (conservation), pembaharuan (inovation) dan penciptaan (creation). Revolusi ilmiah dan transformasi hukum Islam dalam dialektika pemikiran Islam menjadi kenyataan objektif yang terus terjadi sepanjang sejarah (Abdillah, 2003). Sehingga dalam hal ini, memahami paradigma ajaran Islam dibutuhkan berbagai kerangka kerja metodologis yang dapat digunakan sebagai pisau analisis. Kerangka kerja metodologis tersebut dapat ditempuh melalui berbagai pendekatan, selain pendekatan teologis normatif juga terdapat banyak pilihan metode lain, misalnya pendekatan historis, sosiologis antropologis dan pendekatan multidisiplin keilmuan (interdisipliner) yang dalam bahasanya Amin Abdullah diistilahkan/sebagai integrasi dan interkoneksi (Abdullah, 1996).

Senada dengan pandangan Kuhn, bahwa kunci utama revolusi ilmiah ada pada metodologi. Alam tidak serta merta berubah namun metode pencarian penjelasan akan gejala alam kadang-kadang revolutif (perlu perubahan cepat). Sehingga dalam pemikiran Islam, bukan teks al-Qurannya yang dirubah. Namun metodologi dalam memahami teksnya yang harus dirubah (direvolusi).

Agama Islam sebagai agama yang rahmatan lil alamin memiliki ajaran yang sesuai dengan perkembangan zaman dan waktu. Oleh sebab itu, tidak perlu ada pembaharuan terhadap teks terhadap ajaran Islam. Akan tetapi yang perlu diperbarui adalah paradigma manusia terhadap agama dan bukan al-Quran yang harus digugat untuk menghadapi perkembangan zaman (Saefuddin, 1991). Namun dinamika paradigma umat Islam dalam memahami teks al Quran yang terusmenerus dilakukan sepanjang zaman. Dalam hal ini, ayat-ayat Al-Qur'an perlu dipahami dan diberi interpretasi berdasarkan realitas kekinian (Madjid, 1999). Dengan intrepretasi beserta reintrpretasi tersebut menjadikan agama mampu dan sejajar atau bahkan posisinya lebih tinggi dan teratas dalam berdialog dengan kemajuan ilmu pengetahuan dan teknologi.

Berdasarkan tulisan di paragaf sebelumnya bahwa ketika dalam pemaknaan terhadap ajaran Islam ditemukan anomaly (keganjilan/penyimpangan) dari paradigma manusia tentang isi al Qur'an maka perlu diadakan reintrepretasi terhadap teksnya. Sehingga, kajian dapat menggunakan analisis teks dan konteks. Paradigma Kuhn berfungsi untuk perkembangan ilmu pengetahuan juga tidak bisa lepas dari nilai. Termasuk di dalamnya nilai-nilai agama, sosial, dan kemanusiaan. Artinya, ilmu pengetahuan tidak bisa berdiri sendiri. Nilai memiliki fungsi sangat setrategis untuk menentukan arah perkembangan ilmu pengetahuan, tanpa adanya integrasi dari unsur nilai dan ilmu pengetahuan maka ilmu pengetahuan tidak bermakna. 


\section{SIMPULAN}

Paradigma ditempatkan oleh Kuhn sebagai suatu cara pandang, prinsip dasar, metode-metode, dan nilai-nilai dalam memecahkan sesuatu masalah yang dipegang teguh oleh suatu komunitas ilmiah tertentu. Kegiatan ilmiah dibimbing oleh paradigma dalam masa sains normal, dimana para ilmuan berkesempatan mengembangkannya secara terperinci dan mendalam. Ilmuan pun tidak bersikap kritis pada paradigma yang membimbing aktivitas ilmiahnya. Hingga sampai pada fase anomaly ketika ilmuwan menjumpai berbagai fenomena yang tidak bisa diterangkan dengan teorinya dan kemudian terjadilah krisis ilmu pengetahuan. Revolusi ilmiah inilah yang diperlukan dalam upaya memecahkan permasalahan manusia dan menghasilkan paradigma baru setelah terjadinya krisis. Pemikiran Thomas Kuhn tentang proses lahirnya ilmu pengetahuan tersebut dapat dikontekstualisasikan dalam pemikiran dan dinamika keilmuan Islam, terutama dalam membuka mindset ilmuan muslim, bahwa sesungguhnya dalam dinamika keilmuan itu, tidak ada kebenaran keilmuan yang sifatnya mutlak, tetapi selalu terbuka peluang untuk lahirnya pengetahuan baru dengan epistemologi keilmuan baru yang terkadang lebih dapat diterima oleh masyarakat. Sehingga, dalam konteks keilmuan Islam menunjukkan bahwa Islam memiliki dasar pegangan al-Qur'an dan al-Hadits yang diyakini komunitas muslim sebagai kebenaran dan pedoman dalam hidup.

\section{DAFTAR PUSTAKA}

Abdillah, M. (2003). Dialektika Hukum Islam dan Perubahan Sosial: Sebuah Refleksi Sosiologis atas Pemikiran Ibn Qayyim al-Jauziyyah. Surakarta: Surakarta: Muhammadiyah University Press.

Abdullah, A. (1996). Studi Agama: Normativitas atau Historisitas. Yogyakarta: Pustaka Pelajar.

Abid, I. U. dan N. (2015). Pemikiran Thomas Kuhn Dan Relevansinya Terhadap Keilmuan Islam. Jurnal Ilmu Aqidah dan Studi Keagamaan, 3(2), 249-276.

Acikgence, A. (1996). "The Framework for A history of Islamic Philosophy." AlShajarah, Journal of The International Institute of Islamic Thought and Civilization (ISTAC), 1(1-6), 1-15.

Almas, A. F. (2018). Sumbangan Paradigma Thomas S. Kuhn dalam Ilmu Dan Pendidikan (Penerapan Metode Problem Based Learning dan Discovery Learning). Jurnal At-Tarbawi, 3(1), 89-106.

Bakhtiar, A. (2010). Filsafat Agama. Jakarta: Logos Wacana Ilmu.

Drønen, T. S. (2006). Scientific revolution and religious conversion: A closer look at Thomas Kuhn's theory of paradigm-shift. Method and Theory in the Study of Religion, 18(3), 232-253. https://doi.org/10.1163/157006806778553561

Hasbullah, M. (2000). Islamisasi Ilmu Pengetahuan. Jakarta: Pustaka Cidesindo. 
Heilbron, B. J. L. (1998). Thomas. isis, 89(1), 505-515.

Heriyanto, H. (2003). Paradigma holistik Dialog Filsafat, Sains, dan Kehidupan Menurut Shadra dan Whitehead. Jakarta: Teraju.

Hollinger, D. A. (1973). T. S. Kuhn's Theory of Science and Its Implications for History. The American Historical Review, 78(2), 370. https://doi.org/10.2307/1861173

Jena, Y. (2012). Thomas Kuhn Tentang Perkembangan Sains Dan Kritik Larry Laudan. Jurnal Melintas, Department of Ethics/Philosophy, Atma Jaya Catholic University Jakarta, Indonesia, 28(2), 161-181.

Kuhn, Thomas S. (1962). Structure of Scientific Revolutions - Kuhn,Ts. university Of Chicago.

Kuhn, Thomas S. (1976). Theory-change as structure-change: Comments on the sneed formalism. Erkenntnis, 10(2), 179-199. https://doi.org/10.1007/BF00204969

Kuhn, Thomas S. (1962). The Structure of Scientific Revolution. Leiden: Instituut Voor Theoretische Biologie.

Kuhn, Thomas Samuel. (2002). The Structure of Scientific Revolutions Peran Paradigma dalam Revolusi Sains. Bandung: PT Remaja Rosdakarya.

Lubis, A. Y. (2015). Filsafat Ilmu: Klasik Hingga Kontemporer. Jakarta: PT. Raja Grafindo Persada.

Madjid, N. (1999). "Masalah Pendidikan Agama di Perguruan Tinggi Umum," dalam Fuaduddin\&Cik Hasan Bisri (ed.), Dinamika Pemikiran Islam di Perguruan Tinggi. Jakarta: Logos Wacana Ilmu.

Madkoer, I. (1986). Filsafat Islam dan Reneissance Eropa terjemahan Ahmad Tafsir. Bandung: Pustaka.

Meyers, N., Glick, A. F., Mendelsohn, A. L., Parker, R. M., Sanders, L. M., Wolf, M. S., ... Yin, H. S. (2020). Parents' Use of Technologies for Health Management: A Health Literacy Perspective. Academic Pediatrics. https://doi.org/10.1016/j.acap.2019.01.008

Munir, R. M. \& M. (2004). Filsafat Ilmu. Yogyakarta: Pustaka Pelajar.

Murabbi, A. (2014). Revolusi Ilmiah Thomas Samuel Khun (1922-1996) Dan Relevansinya Bagi Kajian Keislaman. Jurnal Mu'ammar Zayn Qadafy, 1(1), 47-59.

Muslih, M. (2016). Filsafat Ilmu: Kajian atas Asumsi Dasar Paradigma dan Kerangka Teori Ilmu Pengetahuan. Yogyakarta: LESFI.

Nurkhalis. (2012). "Konstruksi Teori Paradigma Thomas S. Khun.” Jurnal Ushuluddin, Fakultas Ushuluddin IAIN Ar-Raniry, XI(2), 83.

Orman, T. F. (2016). "Paradigm as a Central Concept in Thomas Kuhn's Thought." International Journal of Humanities and Social Science, 6(10), 47-52.

Patton, M. Q. (1990). Qualitative Evaluation and Research Methods (Second). 
Sage: Newbury Park.

Percival, W. K. (2013). THE APPLICABILITY OF KUHN'S PARADIGMS TO THE HISTORY OF LINGUISTICS. Linguistic Society of America, 52(2), 285-294.

Putra, A. (2015). Epistemologi Revolusi Ilmiah Thomas Khun dan Releveansinya Bagi Studi Al-Qur'an. Jurnal Refleksi, 15(1), 1-15.

Rahman, F. (1987). Neo Modernisme Islam. Bandung: Mizan.

Restivo, S. (2015). THE KUHNIAN REVOLUTION. Wiley, 1(1983), 293-305.

Ritzer, G. (2004). Sosiologi Pengetahuan Berparadigma Ganda, terj. Alimandan (cet. 5). Jakarta: Rajawali Press.

Riyanto, W. F. (2011). Filsafat Ilmu Integral (FIT). Yogyakarta: Integrasi Interkoneksi Press.

Sabila, N. A. (2019). Paradigma dan Revolusi Ilmiah Thomas S. Kuhn (Aspek Sosiologis, Antropologis, dan Historis dari Ilmu Pengetahuan). Jurnal Zawiyah Pemikiran Islam, 5(1), 80-97.

Saefuddin, A. M. (1991). "Pembaharuan Pemikiran Islam: Sebuah Pengantar," dalam Percakapan Cendekiawan tentang Pembaharuan Pemikiran Islam di Indonesia. Bandung: Mizan.

Sardar, Zianuddin. (2002). Thomas Kuhn dan Perang Ilmu. Yogyakarta: Penerbit Jendela.

Sardar, Ziauddin. (2002). Thomas Kuhn dan Perang Ilmu. Yogyakarta: Jendela.

Spruiell, V. (1983). Kuhn's "paradigm" and psychoanalysis. Psychoanalytic Quarterly, 52(3), 353-363. https://doi.org/10.1080/21674086.1983.11927036

Stanfield, R. (1974). Kuhnian Scientific Revolutions and the Keynesian Revolution. Journal of Economic Issues, 8(1), 97-109. https://doi.org/10.1080/00213624.1974.11503164

Syaodih, N. (2010). Metode Penelitian Pendidikan. Bandung: Remaja Rosdakarya.

Upe, D. A. (2010). Asas-Asas Multiple Researches: Dari Nornam K.Denzim hingga John W. Creswell dan Penerapannya. Yogyakarta: Penerbit Tiara Wacana.

Urry, J. (1973). Thomas S. Kuhn as Sociologist of Knowledge. The British Journal of Sociology, 24(4), 462. https://doi.org/10.2307/589735

Wade, N. (1977). Thomas S. Kuhn: Revolutionary theorist of science. Science, 197(4299), 143-145. https://doi.org/10.1126/science.197.4299.143

Walker, T. C. (2010). The perils of paradigm mentalities: Revisiting Kuhn, Lakatos, and Popper. Perspectives on Politics, 8(2), 433-451. https://doi.org/10.1017/S1537592710001180

Watloly, A. (2001). Tanggung Jawab Pengetahuan: Mempertimbangkan Epistemologi secara Kultural. Yogyakarta: Penerbit Kanisius.

Zubaedi, D. (2007). Filsafat Barat: dari Logika Baru Rene Descartes hingga Revolusi Sains ala Thomas Kuhn. Yogyakarta: Ar-Ruzz Media. 